\title{
THE USE OF GROUP INVESTIGATION METHOD TO IMPROVE STUDENTS' SPEAKING ABILITY AT ENGLISH DEPARTMENT OF SORONG MUHAMMADIYAH UNIVERSITY
}

\author{
Amalia Risky Safitri ${ }^{1}$, Muhaiminah Akib², Rezkiah Hartanti \\ 1Department of English Education, Faculty of Teacher Training and Education, University \\ of Muhammadiyah Sorong, Jalan Pendidikan KM 8 Malaingkedi \\ 2Department of English Education, Faculty of Teacher Training and Education, University \\ of Muhammadiyah Sorong, Jalan Pendidikan KM 8 Malaingkedi \\ 2Department of English Education, Faculty of Teacher Training and Education, University \\ of Muhammadiyah Sorong, Jalan Pendidikan KM 8 Malaingkedi
}

This research is aimed to conduct research about using Group Investigation Method to improve students' speaking ability. Therefore, the researcher observed in English Department of Sorong Muhammadiyah University. The researcher uses quantitative method and the design of this research used pre-experimental method with one group pre-test and post-test design. The sample of this research was taken from third semester of class $\mathrm{C}$ in Teacher and Trainning Education Faculty in English Department of Sorong Muhammadiyah University. The sample was taken with randomized sampling and consisted of 30 students. Based on the result teaching reading used collaborative strategy reading at the second year students of SMP Negeri 1 sorong. The researcher found that the teaching reading using collaborative strategy reading did not give much influence to students reading ability. With the use of Collaborative Strategy Reading in teaching and learning made the students very happy and they think that the strategy of reading was interested in improving the foreign language of them. They gave good response and active in the class. Where the mean score of pre test was 31,67 and the mean score of post test was 46,67 and the $t$ - test was 12.5 and $t$ - table was 1.714. Based on the analysis of the research, Collaborative Strategy Reading,did not give much influence to student reading ability. This statement was proved because in control group students also could improve their reading skill well at the second year students of SMP Negeri 1 Sorong When the t- test was 12.5 more high than t- table was 1.714.

Keyword: Group investigation, speaking

\section{Background}

The students expected to playing an active role in all in-class activities (Akib at all, 2018). Group investigation is one form of cooperative learning. In Group Investigation form interest groups within which to plan and implement an investigation, and synthesize the findings into a group presentation for the class. Investigation refers to the fact that groups focus on the process of inquiring about a chosen topic. The vast research literature on the impact of cooperative learning on student success seems to dictate the importance of this classroom structure for classroom teaching and learning (Davidson \& Worsham, 1992; Sharan, 1994). When properly conducted, cooperative learning, a group and student-cantered instructional approach will promote problem-solving skills, social skills and thinking skills of the learner than both individualized and competitive efforts (Johnson \& Johnson, 1991).

Based on descriptions, the researcher is interested to conduct research about using Group Investigation Method to improve 
students' speaking ability. Therefore, the researcher observed in English Department of Sorong Muhammadiyah University.

\section{Review of Related Literature}

The Previous Studies that the researcher in this research is Astri Rahmawati (2014) on her research conducted to describe the implementation of using group investigation strategy to improve students' reading skill of X2 class of MAN Tengaran Semarang and the result of teaching English by group investigation strategy, which was taken as a result of reflection on phenomena done by the researcher. In this research the researcher faced some problems, such as the students had low motivation in joining teachinglearning process and they got the difficulties in reading the text answer the question, they still have problem like vocabulary too. In addition, some of English teachers felt difficult to find the best strategy to teach these reading skills. Here, the researcher chose the group investigation strategy to teach.

\section{Teaching speaking}

Speaking is one of the four language skills (reading, writing, listening and speaking). It is the means through which learners can communicate with others to achieve certain goals or to express their opinions, intentions, hopes and viewpoints. In addition, people who know a language are referred to as 'speakers' of that language. (Torky, 2006). Speaking can be considered as the productive skill of the oral communication which involves other people in conveying the information by pronunciation the words (Wael, 2018).

Lexically, speaking a creative process an active interaction between speaker and listener that involves thought and emotion (underwood, 1997:11) from this definition it is clear that speaking activity can be taken place when there is more than one person speaker and listener. Language learners need to recognize that speaking involves three areas of knowledge: a. Mechanics (pronunciation, grammar, and vocabulary) is using the right words in the right order with the correct pronunciation.

b. Functions (transaction and interaction) is knowing when clarity of message is essential (transaction or information exchange) and when precise understanding is not required (interaction or relationship buliding).

c. Social and cultural rules and norms (turn taking, rule of speech, lenght of pauses, relative roles of participants): understanding how to take into account who is speaking to whom, in what circumstances, about what and for what reason.

\section{Group Investigation Method}

Group Investigation originally designed by Herbert A. Thelen in his book entitled Education and Human Quest thick as 234 pages, published in 1960 in New York. Group investigation method tries to combine in one teaching strategy the form and dynamics of the democratic process with the process of academic inquiry. Thelen tries to reach for an experienced based learning situation, easily transferable to later life situations and characterized by a vigorous level of inquiry. Thelen started with a conception of a social being a man who builds with other men the rules and agreements that constitutes social reality. In cooperating to maintain social agreements, each person assists to ascertain both prohibitions and freedom for action.

\section{Method of the Research}

The design of this research used preexperimental method with one group pretest and post-test design. The design could be described as follows:

Pre-test Treatment Post-test 
$\mathrm{O}_{1}$

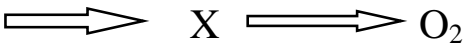

(Sugiyono.2014:75)

Notes:

O1 = Total result of the students' pretest

$\mathrm{X}=$ Treatment by using Group Investigation method

$\mathrm{O} 2=$ Total result of the students' posttest

\section{Population}

The population of this research was students at the third semester at English Department of Sorong Muhammadiyah University, with a total population of this research were 87 students.

Sample

The sample of this research was taken from third semester of class $\mathrm{C}$ in Teacher and Trainning Education Faculty in English Department of Sorong Muhammadiyah University. The sample was taken with unrandomized sampling. The sample of this research consisted of 30 students.

\section{Research Procedure}

In pre-experimental design, one group pre-test and post-test. There were three steps to collect the data as follow:

1. Pre-test

a. The researcher introduced him/herself and asked to the students to pay attention.

b. The researcher asked the students to tell their ideas or opinion about the materials to test students' basic skill in speaking.

c. The researcher gave evaluation score of the students achievement.

2. Treatment

a. The researcher identified the topic and organizing pupils into groups.

b. The students scanned sources, propose topics, and categorize suggestions.

c. The researcher planned the learning task.

d. The students carried out investigation. The students gathered information, analyzed the data and made conclusion.

e. The students prepared a final report. Group members determined the essential message of their project.

f. The students presented the final report. The presentation was made to the entire class in a variety of froms.

g. Evaluation. The students shared feeback about the topic, about the work they did, and about their affective experiences.

3. Post-test

a. The researcher gave the test after by using Group Investigation Method for students.

b. The researcher gave the score based on the student's achievement.

Research Instrument

1. Test

The instrument of this research was a test. The test consisted of some questions/topics for the interview. Assessment included grammar, vocabulary, fluency, pronunciation and content.

2. Scoring speaking test

In scoring the sample, the researcher used the analysis scoring through five components of speaking.

\section{Findings and Discussion}

1. Obtained scores from Pre-test (T1) and Post Test (T2)

To explain result of pre-test and post test score

Table 1

Distribution of Pre Test and Post Test

\begin{tabular}{ccccc}
\hline $\begin{array}{c}\text { No } \\
\cdot\end{array}$ & $\begin{array}{c}\text { Student } \\
\text { s }\end{array}$ & $\begin{array}{c}\text { Pre } \\
\text { Test } \\
\text { (T1) }\end{array}$ & $\begin{array}{c}\text { Post Test } \\
\text { (T2) }\end{array}$ & $\begin{array}{c}\text { Gain } \\
\text { Score } \\
\text { (d) }\end{array}$ \\
\hline 1 & A.A & 40 & 64 & 24 \\
2 & A.F & 40 & 60 & 20 \\
3 & A.J.C.S & 56 & 72 & 16 \\
4 & A.N & 32 & 52 & 20 \\
5 & A.P & 40 & 64 & 24 \\
\hline
\end{tabular}




\begin{tabular}{|c|c|c|c|c|}
\hline 6 & A.P.L & 36 & 52 & 16 \\
\hline & A.RHM & 36 & 56 & \\
\hline 7 & $N$ & & & 20 \\
\hline & $A . R M L$ & 28 & 52 & \\
\hline 8 & $N$ & & & 24 \\
\hline 9 & A.R.P & 48 & 76 & 28 \\
\hline 10 & B. $H$ & 56 & 60 & 4 \\
\hline 11 & D.L.B & 40 & 56 & 16 \\
\hline 12 & D.M.K & 48 & 68 & 20 \\
\hline 13 & E.WNR & 44 & 64 & 20 \\
\hline 14 & E.WT & 44 & 68 & 24 \\
\hline & F.E.N. & 40 & 60 & \\
\hline 15 & $\mathrm{~K}$ & & & 20 \\
\hline 16 & F.N & 28 & 52 & 24 \\
\hline 17 & F.V.M & 32 & 52 & 20 \\
\hline 18 & G.Z.A & 44 & 56 & 12 \\
\hline 19 & $\mathrm{H}$ & 28 & 56 & 28 \\
\hline 20 & H.L & 24 & 36 & 12 \\
\hline 21 & H.N & 36 & 52 & 16 \\
\hline 22 & H.R & 28 & 56 & 28 \\
\hline 23 & I.I.AQ & 28 & 56 & 28 \\
\hline 24 & I.S & 40 & 52 & 12 \\
\hline \multirow[t]{2}{*}{25} & KNDR & 28 & 40 & \multirow[t]{2}{*}{12} \\
\hline & KRYN & 56 & 60 & \\
\hline 26 & $\mathrm{~T}$ & & & 4 \\
\hline 27 & M.F & 36 & 56 & 20 \\
\hline 28 & N.L & 28 & 36 & 8 \\
\hline 29 & P.S & 52 & 64 & 12 \\
\hline 30 & S.W.M. & 28 & 36 & 8 \\
\hline & $\mathrm{N}=30$ & $\begin{array}{l}\sum \mathbf{T}_{\mathbf{1}} \\
=1144\end{array}$ & $\begin{array}{r}\sum \mathbf{T}_{\mathbf{2}}= \\
1684 \\
\end{array}$ & $\begin{array}{l}\sum_{540} \mathbf{d}= \\
\end{array}$ \\
\hline
\end{tabular}

From the table 1 above the researcher computed the mean differences score of pre-test and post-test. From the table, the total score of pre-test $\left(\sum \mathrm{T}_{1}\right)$ was 1144 , and the total score of post-test $\left(\sum \mathrm{T}_{2}\right)$ was 1684 and the total score of gain score $\left(\sum_{d}\right)$ was 540 from 30 students.

\section{The Data of Frequency and Percentage}

Table 4.5

The Data of Frequency and Percentage

\begin{tabular}{ccrrrr}
\hline & & Pre-Test (T1) & \multicolumn{2}{c}{ Post-Test (T2) } \\
\cline { 3 - 6 } Score & $\begin{array}{c}\text { Classifi } \\
\text { cation }\end{array}$ & Freq & $\begin{array}{c}\text { Percen } \\
\text { tage } \\
\%\end{array}$ & $\begin{array}{c}\text { Frequ } \\
\text { ency }\end{array}$ & $\begin{array}{c}\text { Percen } \\
\text { tage } \\
\%\end{array}$ \\
\hline $80.2-$ & Very & - & - & - & - \\
100 & Good & & & & \\
$60.2-$ & Good & - & - & 8 & 26.67 \\
80 & Fair & 9 & 30 & 18 & 60 \\
$40.2-60$ & 21 & 70 & 4 & 13.33 \\
$20.2-40$ & Poor & 21 & - & - & - \\
$0.2-20$ & Very & - & - & 30 & $100 \%$ \\
\hline \multicolumn{2}{c}{ Total $\left(\sum\right)$} & 30 & $100 \%$ &
\end{tabular}

The aim of comparing the results of pre-test and post-test was to know the effect of Group Investigation Method. Besides finding of frequency and percentage, the researcher also found the mean score of the data.

\section{Table of Gain Score Quadrate}

To explain the difference result of pretest score, posttest score, gain score, the mean differences of deviation and gain score quadrate.

Table 4.7

Gain Score Quadrate

\begin{tabular}{|c|c|c|c|c|c|c|}
\hline $\begin{array}{l}\mathrm{N} \\
\mathrm{O}\end{array}$ & $\begin{array}{c}\text { Stu } \\
\text { de } \\
\text { nts }\end{array}$ & $\begin{array}{c}\text { Pre } \\
\text { Tes } \\
\mathbf{t}\end{array}$ & $\begin{array}{c}\text { Pos } \\
\mathrm{t} \\
\text { Tes } \\
\mathrm{t}\end{array}$ & $\begin{array}{c}\text { Gain } \\
\text { Score } \\
\text { (d) } \\
\text { (prete } \\
\text { st- } \\
\text { postte } \\
\text { st) }\end{array}$ & $\begin{array}{c}X_{d} \\
\text { (d- } \\
\text { Md } \\
\text { ) }\end{array}$ & $\begin{array}{c}\text { Gain } \\
\text { Scor } \\
\text { e } \\
\text { Qua } \\
\text { drate } \\
\left(X^{2} d\right. \\
)\end{array}$ \\
\hline 1 & A & 40 & 64 & 24 & 6 & 36 \\
\hline 2 & $\mathrm{AF}$ & 40 & 60 & 20 & 2 & 4 \\
\hline 3 & $\begin{array}{l}\text { A..C } \\
\text {.S }\end{array}$ & 56 & 72 & 16 & -2 & 4 \\
\hline 4 & A.N & 32 & 52 & 20 & 2 & 4 \\
\hline 5 & A.P & 40 & 64 & 24 & 6 & 36 \\
\hline 6 & $\begin{array}{l}\text { A.P. } \\
\text { L }\end{array}$ & 36 & 52 & 16 & -2 & 4 \\
\hline 7 & $\begin{array}{c}\text { A.R } \\
\text { HM } \\
\mathrm{N}\end{array}$ & 36 & 56 & 20 & 2 & 4 \\
\hline 8 & $\begin{array}{c}\mathrm{ML} \\
\mathrm{N}\end{array}$ & 28 & 52 & 24 & 6 & 36 \\
\hline 9 & $\begin{array}{l}\text { A.R. } \\
\text { P }\end{array}$ & 48 & 76 & 28 & 10 & 100 \\
\hline
\end{tabular}




\begin{tabular}{|c|c|c|c|c|c|c|}
\hline 10 & B.H & 56 & 60 & 4 & -14 & 196 \\
\hline 11 & $\begin{array}{c}\text { D.L. } \\
\text { B }\end{array}$ & 40 & 56 & 16 & -2 & 4 \\
\hline 12 & $\begin{array}{c}\text { D.M } \\
\text {.K }\end{array}$ & 48 & 68 & 20 & 2 & 4 \\
\hline 13 & $\begin{array}{l}\text { E.W } \\
\text { NRT }\end{array}$ & 44 & 64 & 20 & 2 & 4 \\
\hline 14 & $\begin{array}{c}\text { E.W } \\
\text { T }\end{array}$ & 44 & 68 & 24 & 6 & 36 \\
\hline 15 & $\begin{array}{l}\text { F.E. } \\
\text { N.K }\end{array}$ & 40 & 60 & 20 & 2 & 4 \\
\hline 16 & F.N & 28 & 52 & 24 & 6 & 36 \\
\hline 17 & $\begin{array}{c}\text { F.V. } \\
\text { M }\end{array}$ & 32 & 52 & 20 & 2 & 4 \\
\hline 18 & $\begin{array}{c}\text { G.Z. } \\
\text { A }\end{array}$ & 44 & 56 & 12 & -6 & 36 \\
\hline 19 & $\mathrm{H}$ & 28 & 56 & 28 & 10 & 100 \\
\hline 20 & H.L & 24 & 36 & 12 & -6 & 36 \\
\hline 21 & H.N & 36 & 52 & 16 & -2 & 4 \\
\hline 22 & H.R & 28 & 56 & 28 & 10 & 100 \\
\hline 23 & $\begin{array}{c}\text { I.I.A } \\
\text { Q }\end{array}$ & 28 & 56 & 28 & 10 & 100 \\
\hline 24 & I.S & 40 & 52 & 12 & -6 & 36 \\
\hline 25 & $\begin{array}{c}\text { KN } \\
\text { DR } \\
\text { N }\end{array}$ & 28 & 40 & 12 & -6 & 36 \\
\hline 26 & $\begin{array}{c}\text { KR } \\
\text { YN } \\
\text { T }\end{array}$ & 56 & 60 & 4 & -14 & 196 \\
\hline 27 & M.F & 36 & 56 & 20 & 2 & 4 \\
\hline 28 & N.L & 28 & 36 & 8 & -10 & 100 \\
\hline 29 & P.S & 52 & 64 & 12 & -6 & 36 \\
\hline 30 & $\begin{array}{l}\text { S.W. } \\
\text { M.A }\end{array}$ & 28 & 36 & 8 & -10 & 100 \\
\hline & $\begin{array}{c}\mathrm{N}=3 \\
0\end{array}$ & $\begin{array}{c}\sum \mathbf{T} \\
\mathbf{1}=1 \\
14 \\
4\end{array}$ & $\begin{array}{c}\sum \mathbf{T} \\
\mathbf{2} \\
=16 \\
84\end{array}$ & $\begin{array}{l}\sum_{\mathbf{d}=}= \\
540\end{array}$ & & $\begin{array}{l}\sum \mathbf{x}^{2} \\
\mathbf{d}=1 \\
400\end{array}$ \\
\hline
\end{tabular}

From the table 4.7 above, it showed the Table of Gain Score Quadrate. Total sum of pretest $\left(\sum_{\mathrm{T} 1}\right)$ was 1144 , total sum of posttest $\left(\sum_{\mathbf{T} 2}\right)$ was 1684 , Total sum of deviation $\left(\sum \mathrm{d}\right)$ was 540 from 30 students and the sum of deviation quadrate $\sum \times 2 \mathrm{~d}$ was 1400 .

It found that the formula of $\mathrm{T}$-test as follows:

$$
\mathrm{t}=\frac{\mathrm{Md}}{\sqrt{\frac{\sum \mathrm{X}^{2} \mathrm{~d}}{\mathrm{~N}(\mathrm{~N}-1)}}}=
$$

$$
\begin{aligned}
& = \\
& \frac{18}{\sqrt{\frac{1400}{30 \times 29}}} \\
& =\frac{18}{\sqrt{1.609}} \\
& =\frac{18}{1.268}
\end{aligned}
$$

$\mathbf{t}=\mathbf{1 4 . 1 9 5}$

\section{Degree of Freedom}

The number of degrees of freedom generally refers to the number of independent observations in a sample minus the number of population parameters that must be estimated from sample data.

$d f$ was definite by formula :

$d f=\mathrm{N}-1$

$\mathrm{N}=$ Number of samples.

$d f=30-1$

$$
=29
$$

\section{T-table.}

T-table is a table showing probabilities (areas) under the probability density function of the $t$ distribution for different degrees of freedom. In statistical significance testing, a one-tailed and twotailed test are alternative ways of computing the statistical significance of a parameter, inferred from a data set, in terms of a test statistic. A two-tailed test is used if deviations of the estimated parameter in either direction from some benchmark value are considered.

- A one-tailed. Also known as directional hypothesis, that have been clearly positive or negative direction. A one-tailed test is a test of significance to determine if there is a relationship between the variables in one direction.

- A two-tailed test, also known as a non directional hypothesis, that without clear direction. A two-tailed test is the standar test or significance to determine if there is a relationship between variables in either direction. 
Based on the statement, the researcher used two-tailed test. From the calculating of $d f$, the result of $d f$ was 29 . Therefore The researcher used the level of significant $(p)=0.05 /$ t.975. From the data above the researcher found the value of $t$-table, it was 2.045

There were two formulation of hypothesis they were null hypothesis $\left(\mathrm{H}_{0}\right)$ and alternative hypothesis $\left(\mathrm{H}_{1}\right)$. The value of t-test was higher than t-table ( $14.195>$ 2.045) it meant that the alternative hypothesis was accepted. There was significance difference in improving the students' in speaking ability before and after treatment by using Group Investigation Method.

\section{Discussion}

The mean score of the pre-test $\left(\mathrm{T}_{1}\right)$ was 1144 and the mean score of the posttest $\left(T_{2}\right)$ was 1684 . It showed that the result of post-test $\left(\mathrm{T}_{2}\right)$ was higher than the result of pre-test.

Considering the discussion above, the researcher argued that the students of English department of Sorong Muhammadiyah University improved their speaking ability after the treatment using Group Investigation Method.

From the higher scores of students' speaking result the researcher would explain based on score speaking from pretest A.J.C.S first of the grammar control of grammar is good. Able to speak the language with sufficient structural accuracy to participate effectively in most formal and informal for example in words "I want to be a good teacher English and I love English". Second of the vocabulary has sufficient speaking vocabulary in words "can speak English more than good reading, speaking be better and all about English I want to be better". Third of the fluency can discuss particular interest of competence with reasonable ease, rarely has to grope for words. Four of the pronunciation errors never interfere with understanding and rarely disturb the native speaker, accent may be obviously foreign in word "English" she pronounced with /'english/ but it should be /'ingglisy/. And the last of the content showed a good understanding of part of the topic.

Score speaking from pre-test F.E.N.K first of the grammar errors in grammar are frequent but speaker can be understood by a native speaker used to dealing with foreigners attempting to speak her language for example in words "we find information all about education". Second of the vocabulary has sufficient speaking vocabulary for example in words "we find information about education, healthy". Third of the fluency can handle with confidence but not with facility for example in words. Four of the pronunciation errors never interfere with understanding and rarely disturb the native speaker, accent may be obviously foreign in word "influence" she pronounced with /'influən/ but it should be /'influəns/, in word "campus" she pronounced with /kampus/ but it should be /'kæmpəs/. And the last of the content she does not seem to understand the topic very well.

Score speaking from pre-test H.L first of the grammar errors in grammar are frequent but speaker can be understood by a native speaker used to dealing with foreigners attempting to speak his language for example in words "Aa because because I I aa....aa....aa....my sister and my brother aa student aa English". Second of the vocabulary speaking vocabulary inadequate to express anything but the most elementary needs for example in words "I I aa job aa in perusahaan". Third of the fluency no specific fluency description, refer to other four language areas for implied level of fluency. Four of the pronunciation accent is intelligible through often quite faulty for example in word "English" he pronounced with /'english/ but it should be /'ingglisy/. And the last of the content completely does not understanding the topic.

Score speaking from post-test A.J.C.S first of the grammar control of grammar is good. Able to speak the 
language with sufficient structural accuracy to participate effectively in most formal and for example in words "In my opinion about application of speaking area in my classroom still minus". Second of the vocabulary can understand and participate with a high degree of precision of vocabulary for example in words "If our everyday speaking English make our skill be better our skill can be ok from before". Third of the fluency can discuss particular interest of competence with reasonable ease. Rarely has to grope for words. Four of the pronunciation errors never interfere with understanding and rarely disturb the native speaker. Accent may be obviously foreign. And the last of the content show a good understanding of the topic.

Score speaking from post-test F.E.N.K first of the grammar errors in grammar can usually handle elementary constructions but does not have through or confident control of the grammar for example in words "And I think the student must to mind in the apply of speaking area and of the that this make a habbit or the culture in semester from semester". Second of the vocabulary able to speak the language with sufficient vocabulary to participate in most formal and informal conversations. Vocabulary is broad enough that rarely has to grope for a word "I think the application of the English language in the classroom has not been emplayed because the student has not been less conscious of how important the application of English in the classroom". Third fluency able to use language fluently on all levels. Can participate with a high degree of fluency. Four of the pronunciation errors never interfere with understanding and rarely disturb the native speaker. Accent may be obviously foreign for example in word "English" she pronounced with /'english/ but it should be /'ingglisy/. And the last of the content show a good understanding of the topic.

Score speaking from post-test H.L first of the grammar errors in grammar are frequent but speaker can be understood by a native speaker used to dealing with foreigners attempting to speak his language for example in words "English English international in world and we can anywhere". Second of the vocabulary has sufficient speaking vocabulary for example in words "we know and for and how to how to speak English". Third of the fluency no specific fluency description, refer to other four language areas for implied level of fluency. Four of the pronunciation errors never interfere with understanding and rarely disturb the native speaker. Accent may be obviously foreign for example in word "know" he pronounced /know/ but it should be /now/. And the last of the content does not seem to understand the topic very well.

\section{The result of testing and hypothesis}

Based on the description of the data above, it meant that t-test value was higher than t-table value. Thus, alternative hypothesis $\left(\mathrm{H}_{1}: 14.195>2.045\right)$ was accepted and null hypothesis $\left(\mathrm{H}_{0}: 14.195<\right.$ 2.045) was rejected. Therefore, as conclusion it could be stated : The Use of Group Investigation Method Could Improve Students' Speaking Ability at English Department Of Sorong Muhammadiyah University.

\section{Conclusion}

This research showed that the mean score of pre-test $\left(\mathrm{T}_{1}\right)$ was 38.13 and the mean score of post-test $\left(\mathrm{T}_{2}\right)$ is 56.13 . It showed that the result of post-test $\left(\mathrm{T}_{2}\right)$ was higher than the result of pre-test $\left(\mathrm{T}_{1}\right)$. The researcher used t-test formula and the result of t-test formula was 14.195 by using the degree of significance $5 \%$ or 0.05 in the t-table it was gotten 2.045. Therefore, alternative hypothesis $\left(\mathrm{H}_{1}\right.$ : $14.195>2.045$ ) is accepted because t-test value was higher than t-table value and null hypothesis $\left(\mathrm{H}_{\mathrm{o}}: 14.195<2.045\right)$ was rejected.

Based on the result above, the researcher concluded that it could be concluded that Group Investigation 
Method was effective to improve students' speaking ability in third grade students at English departement of Sorong Muhammadiyah University especially in teacher and training education faculty.

\section{Reference}

Akib, M., Haryanto, H., Iskandar, I., \& Patak, A. A. (2018). Investigating the motivation, participation, and achievement of students. International Journal of Humanities and Innovation (IJHI), 1(2), 17-27.

Davidson, N. \& Worsham, T. (1992) Enhancing Thinking through Cooperative Learning, New York: Teacher's College Press.

Johnson, David W dkk. (2000). Cooperative Learning Methods: A Meta-Analysis. University of Minnesota. May.

Rahmawati, Astri. (2014). The use of group investigation strategy to improve students' reading skill (a classroom action research of x.2 class of man tengaran, semarang in the academic year 2013/2014). Skripsi. English and education departement State institute for islamic studies (stain) Salatiga.

Sharan, Yael and Sharan, Shlomo.(1990). Group Investigation Harness Students' Individual Interests and Gives Them Even More Control Over Their Learnin Than Other Cooperative Learning Methods Do. Group Investigation Expands

Cooperative Learning.
Sugiyono. (2014). Metode Penelitian Kuantitatif, Kualitatif, dan $R \& D$. Bandung : Alfabeta.

Thelen, Herbert Arnold. (1968). Dynamics of Groups at Work. University of Chicago Press, 1968

Torky, Abd El Fattah, (2006). The effectiveness of a task- based instruction program in developing the English language speaking skills of secondary stage students. Ain Shams University.

Underwood, Mary. (1997). Teaching Listening. New York. Longman Inc

Wael, A., Asnur, M. N. A., \& Ibrahim, I. (2018). Exploring Students' Learning Strategies in Speaking performance. International Journal of Language Education, 2(1), 65-71. 